\title{
DIALEKTIKA IMAN KRISTEN DAN KEBUDAYAAN INDONESIA BERDASARKAN KAJIAN GEERT HOFSTEDE
}

\author{
Edi Purwanto \\ Universitas Bunda Mulia \\ Jl. Lodan Raya No. 2, Ancol, Jakarta Utara \\ Email: epurwanto@bundamulia.ac.id
}

\begin{abstract}
ABSTRAK: Banyak sisi dari iman Kristen, khususnya Injili dan Konservatif yang bertolak belakang dengan kebudayaan Indonesia berdasarkan hasil kajian dan riset Hofstede. Tujuan studi ini adalah mensintesakan dialektika keduanya menggunakan gagasan Christ above Culture dari Niebuhr. Metode riset ini menggunakan dialektika Hegel untuk mensintesakan hubungan dialektika antara kebudayaan Indonesia dan iman Kristen. Hasil penelitian ini adalah sintesa dari: (1) dialektika antara doktrin keselamatan yang bersifat individualistis dengan kebudayaan Indonesia yang kolektivis; (2) dialektika iman Kristen dengan kebudayaan penghindaran ketidakpastian; (3) dialektika ajaran iman Kristen tentang kesetaraan dan kebudayaan jarak kekuasaan; (4) dialektika nilai maskulinitasfemininitas dalam iman Kristen dengan kebudayaan Indonesia yang feminin; dan (5) dialektika orientasi waktu jangka panjang dan jangka pendek dalam perspektif iman Kristen dan kebudayaan Indonesia. Sejumlah solusi alternatif juga diusulkan sebagai aplikasi praktis sintesa-sintesa tersebut bagi pelayanan Injil di Indonesia yang tidak dapat menghindari interaksi dengan kebudayaan setempat.
\end{abstract}

Kata Kunci: iman kristen, injil, kebudayaan, hofstede.

\section{THE DIALECTIC OF CHRISTIAN FAITH AND INDONESIAN CULTURE BASED ON THE STUDY OF GEERT HOFSTEDE}

\begin{abstract}
There are many facets of Christian faith, especially for Evangelicalism and Conservativism, which contradict with Indonesian culture according to Hofstede's study. The aim of this study is synthesizing the dialectics utilizing Christ above Culrture concept of Niebuhr. This method of this study uses Hegel's dialectics to synthesize the dialectical relationship between Indonesian culture and Christian faith. The results of this study are syntheses of: (1) dialectics between individualistic doctrine of salvation and collectivistic of Indonesian culture; (2) dialectic of Christian faith and uncertainty avoidance culture; (3) dialectic of Christian faith on equality and power distance culture, (4) the dialectic of masculinity-femininity culture in the Christian faith and femininity of Indonesian culture; and (5) dialectic of long-term and short-term orientation in the Christian faith perspective and Indonesian culture. A number of alternative solutions are also proposed as practical applications of these syntheses for the gospel ministry in Indonesia that cannot avoid interaction with local cultures.
\end{abstract}

Keywords: christian faith, gospel, culture, hofstede. 


\section{PENDAHULUAN}

Niebuhr (1995, p. 35) berkata, "Beberapa teolog, seperti halnya beberapa antropolog berpendapat bahwa iman Kristen berkaitan secara integral dengan kebudayaan Barat." Ini menunjukkan bahwa keterkaitan antara iman Kristen dan kebudayaan adalah hal yang tidak dapat dielakkan.

Sementara itu, hasil riset dari Geert Hofstede, seorang psikolog sosial, untuk lima dimensi kebudayaan (individualism/collectivism, uncertainty avoidance, power distance, dan masculinity/femininity, dan long-term/short-term orientation), khususnya tentang kebudayaan Indonesia, menunjukkan adanya tantangan baik bagi pelayanan gereja maupun bagi kehidupan orang Kristen itu sendiri di Indonesia. Pertemuan antara ajaran Kristen, khususnya Kristen Injili dan konservatif dengan kebudayaan Indonesia sebagaimana digambarkan dalam lima dimensi taksonomi kebudayaan Hofstede menciptakan pergumulan yang harus dicarikan solusinya dalam pelayanan gereja-gereja Injili Indonesia. Muncul dialektika antara iman Kristen dengan karakteristik kebudayaan Indonesia hasil riset Geert Hofstede.

Artikel ini merupakan usaha untuk: (1) mensintesakan dialektika antara doktrin keselamatan yang bersifat individualistis dengan kebudayaan Indonesia yang kolektivis; (2) mensintesakan dialektika iman Kristen dengan kebudayaan penghindaran ketidakpastian orang Indonesia yang rendah; (3) mensintesakan dialektika ajaran iman Kristen tentang kesetaraan dan kebudayaan jarak kekuasaan dalam masyarakat Indonesia yang tinggi; (4) mensintesakan dialektika nilai maskulinitas-femininitas dalam iman Kristen dengan kebudayaan Indonesia yang feminin; dan (5) mensintesakan dialektika orientasi waktu dalam iman Kristen dengan orientasi jangka panjang dalam kebudayaan Indonesia.

\section{METODE}

Artikel ini adalah hasil studi kualitatif kajian pustaka yang mengambil pendekatan tipe sintesa dalam menghubungkan antara iman Kristen dan kebudayaan, dan oleh sebab itu metode penulisannya menggunakan metode dialektika. Walaupun dialektika merupakan salah satu konsep filsafat tertua yang muncul lebih dari lima ratus tahun sebelum Socrates, Plato juga menggunakan pendekatan dialektika untuk mensintesakan tesis Heraclitus dan antitesanya dari Parmenides, namun kemudian Hegel yang memasukkan Heraclitus, Socrates dan Plato ke dalam teori dialektikanya, Hegel dikenal sebagai seorang ahli dalam dialektika (Lavine, 2003, p. 47). Menurut Lavine (2003, p. 48), Sintesis memiliki tiga fungsi, yaitu: (1) menunda konflik antara tesis dan antithesis, (2) menyimpan elemen kebenaran dari tesis dan antithesis, dan (3) mengungguli perlawanan dan meninggikan konflik hingga mencapai kebenaran yang lebih tinggi. Jadi metode studi pada artikel ini menggunakan pendekatan sintesa atau Christ above Culture oleh Niebuhr dan dialektika Hegel. Data yang dianalisis adalah sumber kepustakaan, khususnya hasil-hasil riset Hofstede dan Alkitab.

\section{HASIL DAN PEMBAHASAN}

Niebuhr (1995, pp. 44-49) menunjukkan lima tipologi atau pendekatan kekristenan terhadap kebudayaan, yaitu: (1) Christ againts Culture yang memandang bahwa kebudayaan manusia pada dasarnya adalah buruk (penuh dosa dan jahat) dan kebudayaan mereka pandang sebagai antithesis (antitesa) iman Kristen, dan oleh sebab itu orang Kristen harus membuat terobosan radikal terhadap kebudayaan mereka; (2) Christ of Culture yang memandang bahwa kebudayaan pada dasarnya baik, dan ada kesetaraan (equates) antara kekristenan dan kebudayaan, dan orang Kristen dapat menemukan Kristus sebagai pahlawan besar dari sejarah kebudayaan, nilai dan kehidupan 
kebudayaan mereka; (3) Christ above Culture yang memandang bahwa paling tidak sebagian dari kebudayaan pada dasarnya baik dan pandangan ini berusaha mensintesakan (synthesis) iman Kristen dengan kebudayaan karena kekristenan walaupun terlepas, namun juga berkesinambungan dengan kehidupan sosial dan kebudayaannya; (4) Christ and Culture in Paradox yang juga memandang bahwa kebudayaan manusia pada dasarnya adalah buruk (penuh dosa dan jahat). Ini adalah tipe dualitas yang memandang orang Kristen berada dalam ketegangan sepanjang hidup antara taat kepada dua otoritas (iman Kristen atau kebudayaan) yang tidak saling bersetujuan namun keduanya harus dipatuhi; dan (5) Christ, Transformer of Culture yang memandang bahwa kebudayaan manusia berusaha menciptakan kebaikan, namun karena sekarang telah terinfeksi oleh dosa maka kebudayaan perlu ditebus dan direstorasi dan orang Kristen harus berusaha mengubah dan kehidupan kebudayaan untuk kemuliaan Allah. Tipe ini disebut tipe conversion atau transformationalists.

Lukito (2011, p. 227) berkata, "Tidak pernah ada Injil yang bebas dari kebudayaan" sehingga "dalam hubungan antara Injil dan kebudayaan patut dicatat bahwa pertanyaan penting yang perlu diperhatikan bukan bagaimana Injil menaklukkan kebudayaan, melainkan bagaimana hubungan antara Injil dan kebudayaan seharusnya." Kemudian Lukito (2011, p. 227) berkata, "Hubungan antara Injil dan kebudayaan kurang lebih sama dengan hubungan antara teks dan konteks. Injil merupakan teks yang harus ditafsirkan artinya, sedangkan kebudayaan adalah konteksnya, sehingga kebudayaan itu juga perlu ditafsirkan." Tentang tipe sintesa (Christ above Culture), Niebuhr (1995, p. 136) berkata "ketika orang Kristen berhadapan dengan masalah Kristus dan kebudayaan, sepanjang masa selalu ada orang yang berpendapat bahwa mereka tidak berurusan dengan satu "yang ini atau yang itu" tetapi suatu hubungan "yang ini dan yang itu." Sebagaimana judul artikel ini adalah "Dialektika Iman Kristen dan Kebudayaan Indonesia dalam Kajian Geert Hofstede", maka sudah tentu bahwa pendekatan tipe sintesa, Christ above Culture adalah pendekatan yang digunakan dalam artikel ini.

Hofstede (1984, p. 4) mendefinisikan kebudayaan sebagai "program mental" (the programming of the mind) dan mengatakan bahwa setiap orang membawa pola berpikir, perasaan, dan potensi tindakan yang dipelajari sepanjang hidupnya, di mana kebanyakan dari pola-pola tersebut diperoleh pada anak usia dini, karena pada saat itu seseorang paling mudah terpengaruh dalam belajar dan berasimilasi. Masyarakat membawa 'program-program mental' yang telah dibangun dalam keluarga sejak masa kanakkanak dan diperkuat di sekolah dan organisasi, dan 'program-program mental tersebut dengan sangat jelas terekspresikan dalam nilai-nilai yang mendominasi di antara masyarakat dari negara yang berbeda-beda. Kebudayaan adalah 'programming of the mind' atau 'culture is the human-made part of the environment' (Lonner and Malpass, 1994, p. 7).

Beralaskan riset yang dilakukan dengan melibatkan lebih dari seratus ribu responden dari 50 negara, Hofstede (2013, p. 184) mengidentifikasi empat dimensi nilai kebudayaan, yaitu individualism/collectivism (individualisme-kolektivisme), uncertainty avoidance (penghindaran ketidakpastian), power distance (budaya jarak kekuasaan), dan masculinity/femininity (budaya maskulinitas-femininitas). Penelitian Hofstede selanjutnya melibatkan peserta dari 23 negara dan menemukan dimensi nilai kebudayaan kelima, yaitu long-term/short-term orientation (budaya orientasi jangka panjang versus jangka pendek).

Berikut ini adalah pemaparan dialektika antara hasil riset Hofstede tentang kebudayaan Indonesia dengan iman Kristen, serta penarikan sintesa yang secara praktis 
diharapkan bermanfaat bagi pelayanan dan kehidupan orang-orang Kristen di Indonesia.

\section{Dialektika Individualisme-Kolektivisme}

Menurut Andersen, Hecht, Hoobler dan Smallwood (2003, p. 77) kebudayaan individualistis menekankan hak-hak dan tanggungjawab pribadi, privasi, menyuarakan pendapat sendiri, kebebasan, inovasi, dan ekspresi diri. Masyarakat individualis memandang tujuan-tujuan personal lebih prioritas dibandingkan kesetiaan mereka pada kelompok, seperti keluarga atau atasan/pemberi pekerjaan. Loyalitas dari orang-orang individualis terhadap kelompoknya sangatlah lemah, mereka menganggap dirinya sebagai bagian dari banyak kelompok dan cenderung untuk berpindah keanggotaan dari satu kelompok ke kelompok lainnya yang lebih menguntungkannya (Purwanto, 2016, p. 37). Individualisme sangat nampak dalam kebudayaan orang Amerika, yang mana komponen-komponen dari individualisme ini di antaranya ialah: (1) individu adalah unit tunggal yang paling penting dalam setting sosial, (2) lebih menekankan independensi ketimbang interdependensi, (3) pencapaian individu sangat dihormati, dan (4) keunikan dari setiap individu dipandang sebagai nilai penting (Samovar, Porter, McDaniel and Roy, 2013, p. 185).

$$
\text { Kebalikan dari kebudayaan }
$$

individualis, Andersen et al. (2003, p. 77) mengatakan bahwa kebudayaan kolektif menekankan komunitas, kolaborasi, kepentingan bersama, harmoni, tradisi, kebaikan masyarakat, dan menjaga martabat. Menurut Samovar et al. (2013, p. 186), masyarakat kolektivisme adalah masyarakat yang mengutamakan kelompok mereka (misalnya, keluarga, suku, dan organisasi) yang mereka percaya telah menjaganya selama ini sehingga mereka merasa berhutang kesetiaan kepada kelompoknya. Menurut Triandis (1990, p. 52) perilaku yang ditemukan dalam kebudayaan kolektif lebih menekankan kepentingan dan tujuan dari kelompoknya ketimbang kepentingan dirinya sendiri, lebih mementingkan norma-norma dan tugas-tugas sosial kelompok ketimbang perilaku mencari kesenangan diri, lebih mempererat hubungan dalam kelompok ketimbang memisahkan diri dari kelompoknya, dan sangat siap untuk bekerja sama dengan para anggota kelompoknya.

Hofstede, Hofstede dan Minkov (2010, p. 107) menyatakan bahwa nilai kebudayaan yang diajarkan Yesus dalam Matius 21:28-31 merupakan nilai kebudayaan individualis. Kebenaran dari isi hati seseorang harus diungkapkan secara jujur walaupun hal tersebut dapat melukai orang lain dalam komunikasi. Namun pengungkapan kebenaran dan kejujuran lebih penting dari pada menjaga perasaan orang lain dengan harus menyangkali kebenaran dan kejujuran. Prinsip tersebut merupakan karakteristik dari masyarakat individualis. Ketika prinsip ini dibandingkan dengan hasil riset Hofstede tentang karakteristik kebudayaan Indonesia, di sana segera muncul suatu dialektika, yang mana iman Kristen sebagai tesis dan kebudayaan Indonesia sebagai anti-tesisnya, karena karakteristik kebudayaan Indonesia adalah kolektivis. Hasil riset Geert Hofstede menemukan bahwa skor individualisme Indonesia rendah (14) yang menunjukkan bahwa masyarakat Indonesia adalah masyarakat kolektivis, di mana individu diharapkan menyesuaikan diri dengan kepentingan kelompok atau masyarakatnya. Itu nampak jelas dalam peran hubungan dalam aspek keluarga. Misalnya, ketika seseorang akan menikah, penting bagi dia untuk menemui keluarga si wanita karena keluarga sangat penting baginya. Anak-anak peduli dan menyayangi orang tua sebagaimana orang tua telah peduli dan menyayangi anak sejak kecil. Membahagiakan orang tua merupakan kerinduan setiap anak Indonesia. Gambaran-gambaran tersebut menunjukkan bahwa masyarakat Indonesia adalah masyarakat kolektivis (Hofstede, n.d.). 
Sekalipun kita mengakui kebudayaan kita sebagai kebudayaan yang luhur, namun bukan berarti kebudayaan kolekvitis kita itu tidak menjadi tantangan bagi pelayanan gereja kita. Tantangan pertama gereja Injili di Indonesia adalah dilema antara ajaran Protestan atau Injili tentang keselamatan yang bersifat individual dan kebudayaan kolektivisme Indonesia. Gereja Injili mengajarkan bahwa menurut Firman Tuhan, seseorang diselamatkan oleh karena anugerah kepada individu yang dipilih. Individu yang telah dipilih Allah menerima outward calling dan inward calling lalu mengambil keputusan secara pribadi untuk menerima dan percaya kepada Yesus Kristus. Namun praktiknya ada banyak orang mengambil keputusan untuk menjadi atau tidak menjadi Kristen karena pertimbangan-pertimbangan kelompok, misalnya keluarga atau masyarakat. Maka tidak mengherankan bila kita membaca laporan kisah-kisah misionaris di Indonesia yang dapat "memenangkan" dan membaptiskan satu suku setelah "memenangkan" kepala suku mereka. "Memenangkan" dan membaptis seluruh anggota keluarga, setelah "memenangkan" kepala keluarganya. Dilihat dari nominal itu bisa dipandang sebagai keberhasilan pelayanan misi, namun dilihat dari kualitas masih ada kegagalan di sini jika tidak dilakukan pemeriksaan dengan seksama atau menguji setiap individu yang bertobat dan akan dibaptis apakah mereka benar-benar telah diselamatkan, atau hanya 'ikut-ikutan' atau terpengaruh oleh masyarakat atau keluarganya. Prinsip individualis harus memeriksa satu per satu individu, namun prinsip kolektivis tindakan misionaris memeriksa satu per satu individu akan dianggap sebagai tindakan ketidakpercayaan motif individu dan dapat melukai bukan hanya individu, namun seluruh individu dalam masyarakatnya. Setiap individu dalam masyarakat kolektivis tidak bisa melihat individu lain dalam masyarakatnya terluka atau dilukai.

Lalu sintesa seperti apa yang dapat diusulkan sebagai solusi dari dialektika terse- but? Ketika satu keluarga atau bahkan satu suku atau masyarakat memberi diri dibaptis karena kepala keluarga atau kepala suku mereka bertobat dan memberi diri dibaptis, dalam prinsip Kristen harus tetap memastikan bahwa setiap orang yang akan dibaptis haruslah orang-orang yang benarbenar telah diselamatkan secara individu, bukan ikut-ikutan. Maka setiap calon baptisan harus diuji dan diperiksa dengan seksama. Namun seperti disinggung di atas, hal tersebut dapat melukai bukan hanya individu tersebut, namun juga individuindividu lain dalam keluarga atau masyarakatnya dan tentu akibatnya mereka semua bisa membatalkan diri untuk bergabung dalam gereja dan membatalkan kesediaannya untuk dibaptis. Sementara jika demi menjaga harmoni gereja harus menerima dan membaptiskan mereka semua tidak peduli motif dan kondisi jiwa setiap individu, pembaptisan hanya akan memasukkan orang-orang yang mungkin belum bertobat dan diselamatkan menjadi bagian dari gereja lokal, dan seringkali akan menjadi pembuat masalah dalam gereja di masa depan. Pemeriksaan setiap individu dengan hati-hati sambil menjaga hati dan perasaan mereka dan mencari alasan yang logis untuk penundaan pembaptisan secara masal bisa menjadi usulan solutif. Walaupun tentu hal tersebut juga akan segera memunculkan pertanyaan, "Sampai kapan?", namun itu dapat menjadi salah satu solusi alternatif.

Tantangan lainnya yang dihadapi gereja di Indonesia adalah bahwa seringkali jemaat mengaminkan atau mengiyakan apa yang dinasihatkan pendeta atau apa yang diajarkan atau dikhotbahkan dari Alkitab, namun pada praktiknya mereka mungkin tidak melaksanakan nasihat atau ajaran tersebut. Ketika pendeta menasihatkan atau berkhotbah bahwa orang Kristen sudah diselamatkan, maka tidak perlu slametan, Alkitab melarang orang Kristen untuk "memelihara hari-hari” (Galatia 4:10-11), dan sebagainya, mungkin mereka akan menjawab. "lya". Namun praktiknya mereka tetap 
mengadakan slametan yang seringkali dikamuflasekan dengan istilah syukuran, dan masih memelihara hari-hari tertentu seperti telon-telon, pitonan, selapanan dan sebagainya. Selalu mengiyakan atau mengaminkan adalah demi menjaga harmoni dalam hubungan keluarga Tuhan dalam masyarakat kolektivis. Ini merupakan tantangan pelayanan di Indonesia.

Yesus memberi perumpamaan seperti berikut: "Seorang mempunyai dua anak lakilaki. la pergi kepada anak yang sulung dan berkata: Anakku, pergi dan bekerjalah hari ini dalam kebun anggur. Jawab anak itu: Baik, bapa. Tetapi ia tidak pergi. Lalu orang itu pergi kepada anak yang kedua dan berkata demikian juga. Dan anak itu menjawab: Aku tidak mau. Tetapi kemudian ia menyesal lalu pergi juga" (Mat. 21:28-30). Kemudian Yesus bertanya kepada para pendengarnya, "Siapakah di antara kedua orang itu yang melakukan kehendak ayahnya?' (Mat. 21:31). Lalu apa jawab mereka? Mereka menjawab, "Yang terakhir" (Mat. 21:31). Menurut Hofstede et al. (2010, p. 107) jawaban mereka menunjukkan nilai kebudayaan individualis, yang mana dalam kebudayaan individualis, mengatakan kebenaran tentang apa yang seseorang rasakan merupakan karakteristik dari orang yang tulus dan jujur. Perbedaan pendapat diyakini dapat melahirkan kebenaran yang lebih tinggi. Anakanak diharapkan dapat mengatakan yang sebenarnya, meskipun itu menyakitkan. Mengatasi konflik adalah bagian normal dari hidup bersama sebagai keluarga.

Namun menurut Malina dan Rohrbaugh (2003, p. 109), dalam masyarakat Mediterania pada abad pertama yang kolektivis, anak pertama yang menjawab, "Baik, bapa," tetapi ia tidak pergi, adalah anak yang membuat ayahnya merasa tenang, ia adalah anak yang berperilaku baik, anak laki-laki yang baik, namun ia tidak melakukan apa yang berkenan di hati ayahnya. Perilaku demikian sering ditunjukkan dalam masyarakat kolektivis, termasuk dalam masyarakat Indonesia. Hofstede et al. (2010, p. 107) menulis tentang seorang mantan misionaris Belanda di Indonesia yang pernah menceritakan tentang penafsiran yang tak terduga dari umatnya tentang perumpamaan di atas. Ketika sang misionaris bertanya kepada umatnya dengan mengulang pertanyaan Yesus, "Siapakah di antara kedua orang itu yang melakukan kehendak ayahnya?' Umatnya memilih yang pertama (anak yang sulung), karena si sulung berusaha untuk mempertahankan harmoni dan tidak ingin bertentangan dengan ayahnya. Entah akhirnya dia melakukan apa yang ayahnya perintahkan atau tidak, itu hal sekunder. Mengapa demikian karena Indonesia memiliki kebudayaan kolektivis. Untuk menjaga harmoni dalam masyarakat kolektivis dianjurkan untuk tidak memberikan jawaban-jawaban yang bersifat kontra. Jawaban "tidak" dapat merusak harmoni. Itulah sebabnya, orang jawa selalu menjawab "inggih" walapun "inggih, ning ora kepanggih" (menjawab iya, namun tidak dilaksanakan). Setuju pada saat menerima perintah adalah tindakan yang sopan dan menjaga harmoni terlepas akhirnya dilaksanakan atau tidak. Menolak pada saat menerima perintah akan langsung merusak harmoni, walaupun akhirnya ia menjalankan perintah, orang tua sudah tidak berkenan lagi atas apa yang dikerjakannya karena sudah terluka di awal.

Catatan Alkitab, penjelasan Hofstede dan kesaksian misionaris di atas menunjukkan adanya dialektika karakteristik individualis iman Kristen dalam ajaran Yesus dan kebudayaan Indonesia yang kolektivis. Lagi-lagi ini menjadi tantangan dalam pelayanan gereja di Indonesia. Dalam menjaga harmoni seringkali orang-orang Kristen menyangkali kebenaran dan kejujuran dalam sikap (non-verbal communication) maupun perkataanya (verbal communication), sehingga apa yang ditunjukkan atau dikatakannya adalah kepalsuan dan kemunafikan. Misalnya takut melukai perasaan anggota jemaat yang berdosa, mungkin saja gereja berada dalam dilema. 
Karena jika menegur atau menasihati orang yang berbuat dosa tersebut dapat melukai perasaannya, dan akibatnya jika orang itu merupakan anggota keluarga besar yang juga berjemaat di gereja tersebut dapat menyebabkan anggota keluarganya ikut terluka. Jika orang yang dinasihati karena berdosa keluar dari gereja, mungkin akan segera diikuti oleh saudara-saudaranya yang bergereja di gereja itu. Ketika orang Kristen harus mengatakan apa yang benar menurut kebenaran Firman Tuhan seringkali menimbulkan benturan dan keretakan harmoni dalam masyarakat, dan kepada orang yang demikian juga akan dicap munafik, karena hanya bisa bicara kebenaran namun tidak dapat hidup berdampingan dengan harmoni bersama masyarakat, tidak memiliki kasih, tidak bisa mengampuni, dan sebagainya. Seperti pernah dikatakan oleh Wibisono (1990, p. 60) bahwa dalam masyarakat kita yang kolektivis, orang tidak akan terpengaruh oleh khotbah kita dan menganggap kita munafik ketika dalam pergaulan kita tidak mencerminkan kasih yang tercermin dalam interaksi sehari-hari dalam pola hidup horizontal.

Sintesa sebagai solusi dari dialektika tersebut sering dilakukan oleh para pemimpin gereja dengan cara sebaik mungkin untuk menasihati anggota jemaat yang jatuh ke dalam dosa. la akan menjaga perasaan orang tersebut, tidak membiarkan orang tersebut kehilangan muka, tidak mempermalukannya, namun menasihati dengan bijak dan kasih sayang. Dengan demikian ia tetap menyampaikan kebenaran, namun dengan mencari cara yang bijak sehingga tidak melukai hati orang yang dinasihatinya.

\section{Dialektika Penghindaran Ketidakpastian}

Penghindaran ketidakpastian (uncertainty avoidance) didasarkan pada kenyataan bahwa masa depan tidak dapat diketahui. Prediksi seseorang tentang masa depan tidak pernah seratus persen sesuai dengan apa yang diharapkan. Menurut Hofstede et al. (2010, p. 191), ketika orang-orang dalam suatu kebudayaan ragu dengan situasi yang tidak terstruktur, tidak jelas, atau tidak dapat diprediksi, maka mereka mencoba untuk menghindari ambiguitas atau ketidakpastian tersebut. Itulah apa yang dimaksud dengan penghindaran ketidakpastian. Kebudayaan dengan penghindaran ketidakpastian tinggi berusaha untuk menghindari ketidakpastian dan ambiguitas dengan disertai tingkat kecemasan dan ketertekanan yang tinggi. Sebaliknya, dalam kebudayaan penghindaran ketidakpastian rendah mereka lebih mudah menerima ketidakpastian yang melekat dalam hidup mereka, cenderung toleran dengan sesuatu yang tidak biasa, dan tidak merasa terancam oleh gagasan-gagasan atau masyarakat yang berbeda (Samovar et al., 2013, p. 187).

Hofstede et al. (2010, p. 226) mengatakan bahwa di kebanyakan negara Kristen Katolik dan Ortodoks memiliki skor penghindaran ketidakpastian yang tinggi, sedangkan skor penghindaran ketidakpastian rendah di negara-negara Kristen Protestan. Kaum Injili percaya bahwa setiap orang percaya memiliki jaminan kekal keselamatan. Kepastian masuk surga menyebabkan penghindaran ketidakpastian menjadi rendah "karena bagiku hidup adalah Kristus dan mati adalah keuntungan" (Flp. 1:21). Sementara terkait dengan ketidakpastian di dalam dunia ini Yesus mengajarkan, "Janganlah kuatir akan hidupmu, akan apa yang hendak kamu makan atau minum, dan janganlah kuatir pula akan tubuhmu, akan apa yang hendak kamu pakai ... Pandanglah burung-burung di langit, yang tidak menabur dan tidak menuai dan tidak mengumpulkan bekal dalam lumbung, namun diberi makan oleh Bapamu yang di sorga. Bukankah kamu jauh melebihi burungburung itu?' (Mat. 6:25-26). Kebergantungan penuh kepada Kristus melalui iman baik dalam hidup saat ini maupun kehidupan yang akan datang menyebabkan tingkat penghindaran ketidakpastian orang Kristen menjadi rendah. Kepercayaan dan ketulusan terhadap orang lain sebagaimana diajarkan 
Alkitab juga membuat tingkat penghindaran ketidakpastian orang Kristen menjadi rendah.

Riset Hofstede menemukan dimensi kebudayaan penghindaran ketidakpastian Indonesia masih tergolong rendah namun dengan skor 48, mendekati skor 50 yang merupakan batas antara penghindaran ketidakpastian tinggi dan rendah. Kebudayaan Jawa memisahkan antara internal self dan external self. Ketika seseorang sedang kesal, sudah menjadi kebiasaan bagi orang Indonesia untuk tidak menunjukkan emosi atau kemarahan negatifnya secara eksternal. Mereka akan tetap tersenyum dan bersikap sopan, tidak peduli seberapa marahnya di dalam hati mereka (Hofstede, n.d.). Itu juga menyebabkan tingkat kepercayaan orang Indonesia kepada orang lain dan keadaan biasanya tinggi. Sehingga tidak sulit bagi orang Kristen Indonesia untuk mengsinkronkan antara kebudayaan Kristen dan kebudayaan Indonesia terkait nilai kebudayaan penghindaran ketidakpastian. Karena jika karakteristik Kekristenan sendiri menunjukkan kebudayaan penghindaran ketidakpastian rendah, kebudayaan Indonesia memiliki dimensi penghindaran ketidakpastian rendah pula.

Namun demikian, tetap ada dialektika antara iman Kristen dan kebudayaan penghindaran ketidakpastian Indonesia. Alkitab mengajarkan untuk bergantung penuh kepada Tuhan, dan menghilangkan kekuatiran di dalam hidup yang telah diserahkan kepada Tuhan, namun di sisi lain, skor 48 penghindaran ketidakpastian kebudayaan Indonesia menunjukkan bahwa orang Kristen Indonesia belum bisa sepenuhnya bergantung pada Tuhan. Kekuatiran masih seringkali memenuhi hati orang Kristen. Sintesa dari dialektika tersebut adalah gereja harus lebih sering mengkhotbahkan dan mengajarkan tentang kepastian pemeliharaan Tuhan dalam kehidupan orang percaya, agar jemaat semakin menyadari dan menggantungkan hidupnya secara penuh kepada Tuhan, dan tiap-tiap hari kekuatiran di dalam hatinya menjadi semakin berkurang. Untuk melakukan hal tersebut akan lebih mudah, karena di dukung oleh skor kebudayaan penghindaran ketidakpastian orang Indonesia yang tidak terlalu tinggi. Sehingga diharapkan bahwa kecenderungan orang Kristen Indonesia untuk percaya pada janji pemeliharaan Tuhan sebagaimana tertulis di dalam Alkitab adalah tinggi, dengan cara yang diusulkan di atas dapat meningkatkan kepercayaan orang Kristen Indonesia kepada pemeliharaan Tuhan dan mengurangi kekuatiran dalam hidup mereka.

\section{Dialektika Jarak Kekuasaan}

Hofstede et al. (2010, p. 55) mengatakan bahwa jarak kekuasaan terkait dengan bagaimana masyarakat menyadari fakta adanya ketidaksetaraan dalam masyarakat. Menurut Gudykunst (2001, p. 41), individu dari kebudayaan jarak kekuasaan tinggi menerima kekuasaan sebagai bagian dari masyarakat. Dengan demikian, atasan menganggap bawahan mereka berbeda dengan mereka dan demikian juga sebaliknya. Samovar et al. (2013, p. 189), mengatakan bahwa disadari atau pun tidak disadari kebudayaan tersebut membuat anggota kebudayaan untuk menerima bahwa status dalam masyarakat tidaklah setara. Ada orang-orang yang memiliki hak istimewa dan sementara yang lain harus menyadari keberadaannya yang lebih rendah. Itu dapat berlaku dalam lembaga keluarga, masyarakat, organisasi, atau negara. Sebaliknya negara-negara dengan nilai kebudayaan jarak kekuasaan rendah berkeyakinan bahwa ketidaksetaraan dalam masyarakat harus diminimalisir. Atasan dan bawahan dipertimbangkan setara (Samovar et al. (2013, p. 189).

Gereja Injili di Indonesia berada di dalam dilema antara ajaran Kristen yang menjunjung kesetaraan dengan kebudayaan jarak kekuasaan Indonesia yang tinggi. Di satu sisi, menurut Hofstede at al. (2010, p. 80), orangorang Kristen Perjanjian Baru pada abad pertama memberitakan tentang perlunya keba- 
jikan terhadap orang-orang miskin, dan dalam mengejar kebajikan tersebut akan mengarah pada kesetaraan dalam masyarakat. Perhatian atas masalah kemiskinan di dalam Alkitab dapat dilihat sebagai sebuah manifestasi kerinduan akan kesetaraan (Hofstede at al., 2010, p. 54). Namun dalam perkembangannya, menurut Hofstede at al. (2010, p. 80), Gereja Roma Katolik telah mempertahankan tatanan hierarkis dari Kekaisaran Romawi, demikian juga dengan gereja-gereja Ortodoks Timur, sedangkan tatanan pada denominasi-denominasi Protestan kurang bersifat hierarkis. Itulah sebabnya negara-negara Protestan cenderung memiliki skor jarak kekuasaan yang lebih rendah ketimbang negara-negara Katolik dan Ortodoks. Namun, di sisi lain, hasil riset Geert Hofstede menemukan bahwa dimensi kebudayaan jarak kekuasaan Indonesia tinggi (skor 78) yang ditandai dengan kebergantungan pada hierarki, ketidaksetaraan hak antara pemegang kekuasaan dan yang tidak memegang kekuasaan, keterbatasan akses kepada pimpinan. Dalam kebudayaan jarak kekuasaan tinggi ini bawahan cenderung memerlukan arahan yang jelas dari atasan. Di sini terdapat juga penerimaan sosial ketidaksetaraan dan jurang pemisah antara si kaya dan si miskin (Hofstede, n.d).

Kebudayaan jarak kekuasaan masyarakat Indonesia yang tinggi tidak berarti mereka menerima perbedaan kekuasaan karena takut, namun karena respek dan demi menjaga tatanan dalam hubungan masyarakat. Sehingga walaupun masyarakat respek kepada para pemangku kekuasaan atau posisi tinggi, mereka juga mengharapkan adanya tepa slira (empati) yang ditunjukkan pemimpinan kepada bawahannya. Seorang pemimpin harus dapat menjadi bapak yang dapat mengayomi mereka yang dipimpin. Hubungan antara Punakawan (hamba) dan Pandawa (tuan mereka) dalam Pewayangan menggambarkan kebudayaan jarak kekuasaan tinggi dan tepa slira yang tinggi pula. Punakawan sangat menghormati
Pandawa, sementara Pandawa juga menghargai Punakawan dalam sikap dan tutur kata (Purwanto, 2018, p. 6).

Dengan demikian menerima jarak kekuasaan sekaligus menekankan tepa slira dalam masyarakat dan gereja itu sendiri merupakan sintesa dari dialektika antara kebudayaan jarak kekuasaan tinggi Indonesia dan nilai kesetaraan yang harus dijunjung menurut ajaran Alkitab. Orang Kristen Indonesia harus hidup saling menghormati untuk menjaga harmoni dalam masyarakat kolektivis. Bawahan menghormati atasan, rakyat menghormati pemimpin mereka, anak menghormati orangtua, yang muda menghormati yang lebih tua, namun di saat yang sama atasan harus ngayomi dan menjadi teladan bagi bawahan, pemimpin harus ngayomi dan menjadi teladan rakyatnya, orang tua harus ngayomi dan menjadi teladan bagi anak-anak mereka, yang lebih tua harus ngayomi dan menjadi teladan bagi yang muda. Ketika jemaat menerima adanya jarak kekuasaan berdasarkan kelas sosial dan ekonomi, pemimpin gereja harus memandang jemaat yang paling rendah kelas sosialnya atau paling miskin dalam gereja setara dengan orang yang paling kaya atau kelas paling terhormat dalam masyarakat, baik dalam sikap, perkataan maupun dalam perlakuan. Di mata Tuhan semua orang sama tinggi, walaupun mereka berbeda menurut kelas sosial dalam masyarakat.

Demi menjaga harmoni dalam pranata masyarakat, orang Kristen harus menerima fakta ketidaksetaraan antara pemimpin dan yang dipimpin, antara yang dituakan dan yang muda, namun di sisi lain, secara esensi orang Kristen Indonesia tetap dapat menjunjung nilai kesetaraan karena setiap orang harus menghargai orang lain, sekalipun pemimpin terhadap bawahannya. Hubungan antara Punakawan dan Pandawa di atas menggambarkan penerimaan ketidaksetaraan sekaligus secara esensi menjunjung tinggi kesadaran akan kesetaraan, sebagaimana dikatakan oleh Karl Barth, "Manusia itu bukan manusia 
tanpa sesamanya manusia" (Ukur, 2011, p. 245).

Kompas pernah melansir laporan survei Burson-Marsteller bahwa masyarakat Indonesia lebih menghormati para pemimpin agama ketimbang pemimpin Negara (Purwanto, 2018, p. 8). Keuntungan dari kebudayaan jarak kekuasaan yang tinggi ini bagi pelayanan gerejawi adalah bahwa jemaat menunjukkan rasa hormat yang tinggi kepada pemimpin gereja. Mereka menaruh kepercayaan yang tinggi atas apa yang diajarkan atau dikhotbahkan oleh pendeta. Namun tantangannya adalah jika ajaran pendetanya menyimpang, maka jemaat juga mudah percaya dan terbawa ke dalam penyimpangan. Tantangan lainnya adalah bagi para pemimpin gereja itu sendiri. Karena posisinya yang tinggi dan sangat dihormati bisa membuat mereka menyalahgunakan posisinya untuk kepentingan pribadinya, seperti apa yang disebut Russell (2009, p. 194) sebagai kecacatan profesi kependetaan. Sintesa dari dialektika tersebut, para pemimpin gereja harus mengajarkan kebenaran sesuai ajaran Alkitab dan tidak memanfaatkan kedudukannya sebagai pendeta untuk kepentingan atau keuntungan pribadi sehingga mengkhianati panggilannya. Jemaat akan mendengarkan pendeta dan pendeta dapat memimpin mereka kepada jalan kebenaran karena jemaat sangat menghormati dan mengakui kedudukan pendeta sebagai orang yang dipanggil dan ditetapkan oleh Tuhan itu sendiri.

\section{Dialektika Maskulinitas-Femininitas}

Hofstede menggunakan istilah maskulinitas dan femininitas untuk mengacu nilai-nilai yang terkandung dalam maskulinitas dan femininitas tersebut (Samovar et al., 2013, p. 190). Menurut Hofstede et al. (2010, p. 140), kebudayaan maskulinitas pada umumnya mengharapkan seseorang untuk bersikap tegas, ambisius, dan kompetitif, menghormati apa pun yang besar, kuat, dan cepat. Sedangkan nilai-nilai kebudayaan femininitas ditunjukkan dengan nilai-nilai interdependensi, simpati terhadap yang tidak beruntung (Samovar et al., 2013, p. 191). Hasil riset Hofstede menemukan bahwa skor dimensi maskulinitas Indonesia tergolong rendah (46), sehingga hal tersebut menunjukkan bahwa kebudayaan Indonesia adalah feminin. Kemudian menurut Hofstede et al. (2010, p. 176), kebudayaan di negaranegara Katolik cenderung maskulin, sedangkan negara-negara Protestan cenderung feminin. Sedangkan Alkitab menekankan keseimbangan hubungan maskulinitas dengan femininitas (Hofstede et al., 2010, p. 177).

Hofstede et al. (2010, p. 176) mengatakan bahwa Kekristenan sendiri selalu mempertahankan tarik-menarik antara ketegasan (elemen maskulin) dan kelembutan (elemen feminin). Perjanjian Lama merefleksikan nilai-nilai yang lebih tegas (mata ganti mata, gigi ganti gigi), sementara Perjanjian Baru lebih merefleksikan nilai-nilai yang lebih lembut (jika kamu ditampar pipi kirimu, berikanlah pipi kananmu). Karakteristik Allah Perjanjian Lama adalah keagungan (majestic), sedangkan Yesus dalam perjanjian Baru membantu mereka yang lemah dan menderita. Injil menawarkan skala maskulinitas dan femininitas. Perjanjian Baru menekankan keseimbangan hubungan dengan Allah (maskulinitas) dan dengan sesama manusia (femininitas) (Hofstede et al., 2010, p. 177). Hofstede et al. (2010, p. 177) mengatakan bahwa karena banyak negara Kristen yang lebih menekankan maskulinitas, sementara yang lain lebih menekankan femininitas, menyiratkan bahwa keseimbangan antara kedua perintah itu sulit ditemukan. Ajaran Alkitab sendiri telah memberikan sintesa dari dialektika kebudayaan Indonesia dan kebudayaan dari negara-negara Protestan yang cenderung feminin dengan kebudayaan-kebudayaan di negara Katolik yang cenderung maskulin.

Gereja dan pemimpin gereja harus bijak kapan mengambil sikap tindakan maskulin dan feminin. Berkaitan dengan masalah dosa 
dan kebenaran, gereja dan pemimpin gereja harus mengambil sikap maskulin, yaitu dengan tegas menolak untuk permisif, mentolerir dan ragu-ragu dalam menyikapi jemaat yang jatuh dalam dosa. Orang yang jatuh ke dalam dosa harus ditegur dengan Firman Tuhan, karena Alkitab diilhamkan dan "bermanfaat untuk mengajar, untuk menyatakan kesalahan, untuk memperbaiki kelakuan dan untuk mendidik orang dalam kebenaran" (2 Tim. 3:16). Namun demikian gereja dan pemimpin gereja juga harus menunjukkan sisi feminin dalam menegur mereka yang jatuh ke dalam dosa, karena tujuan menegur, mengajar dan menyatakan kesalahan tersebut adalah demi "memperbaiki kelakuan dan untuk mendidik orang dalam kebenaran", bukan untuk menghancurkan dan membinasakannya. Oleh sebab itu, lakukanlah hal itu dengan penuh simpati dan lakukan menurut cara yang Alkitab telah ajarkan. Yesus pernah mengajar demikian: "Apabila saudaramu berbuat dosa, tegorlah dia di bawah empat mata. Jika ia mendengarkan nasihatmu engkau telah mendapatnya kembali. Jika ia tidak mendengarkan engkau, bawalah seorang atau dua orang lagi, supaya atas keterangan dua atau tiga orang saksi, perkara itu tidak disangsikan. Jika ia tidak mau mendengarkan mereka, sampaikanlah soalnya kepada jemaat. Dan jika ia tidak mau juga mendengarkan jemaat, pandanglah dia sebagai seorang yang tidak mengenal Allah atau seorang pemungut cukai" (Mat. 18:1517). Yesus memberikan tahapan-tahapan tersebut dengan tujuan untuk menjaga saudara yang berdosa agar tidak dipermalukan, sehingga mulailah dengan menegor "dia di bawah empat mata" dan berharap agar "jika ia mendengarkan nasihatmu engkau telah mendapatnya kembali." Ini adalah sisi feminin dalam praktik pelayanan gereja. Jadi ajaran Alkitab yang maskulinitas-femininitas dengan sendirinya menjadi sintesa dari dialektika kebudayaan Indonesia yang feminin dan kebudayaan beberapa negara Kristen yang maskulin, walaupun ada juga kebudayaan negara Kristen yang feminin.

\section{Dialektika Orientasi Jangka Panjang Vs. Jangka Pendek}

Setelah bertahun-tahun kemudian, Hofstede melakukan penelitian di dua puluh tiga negara, dengan menggunakan pengukuran Chinese Value Survey (CVS), yang mana instrumen tersebut dikembangkan Michael Harris Bond di Hong Kong dari nilai-nilai yang diusulkan oleh para sarjana Tionghoa. Dari sana kemudian Hofstede menawarkan dimensi kebudayaan yang kelima, yaitu kebudayaan berorientasi jangka panjang vs. jangka pendek. Hasil penelitian Hofstede tersebut menunjukkan bahwa kebudayaan yang berorientasi jangka panjang memungkinkan memiliki karyawan yang merefleksikan etos kerja yang kuat dan menunjukkan respek yang besar terhadap perbedaan status. Sedangkan kebudayaan yang berorientasi jangka pendek sering tidak menempatkan prioritas tinggi pada status, berorientasi jangka pendek dan ingin mencari keuntungan dan memenuhi kebutuhan mereka dengan cepat (Samovar et al., 2013, p. 192).

Hasil riset Geert Hofstede menemukan bahwa Indonesia memiliki kebudayaan orientasi jangka panjang yang tinggi dengan skor 62. Menurut Hofstede skor tersebut mengindikasikan bahwa Indonesia memiliki kebudayaan pragmatis, yang mana dalam masyarakat dengan orientasi pragmatis, mereka percaya bahwa kebenaran tergantung pada berbagai macam situasi, konteks dan waktu. Mereka memiliki kemampuan untuk mengadaptasi tradisi dengan mudah dan cepat berubah menyesuaikan kondisi. Sementara jika dibandingkan dengan pendirian Kristen konservatif dan fundamentalis, Hofstede et al. (2010, p. 269) berkata bahwa Kekristenan konservatif atau fundamentalisme merepresentasikan kutub orientasi jangka pendek yang ekstrim, di mana keputusan-keputusan diambil tidak berdasarkan situasi hari ini, namun didasarkan pada interpretasi tentang apa yang tertulis dalam 
Kitab Suci. Dengan demikian ada prinsip yang bertolak belakang antara kebudayaan Indonesia yang berorientasi waktu jangka panjang dan prinsip Kristen konservatif yang berorientasi waktu jangka pendek. Di satu sisi, kemampuan orang Indonesia untuk mengadaptasi tradisi dengan mudah dan cepat berubah menyesuaikan kondisi menjadi peluang misi gereja untuk memberikan pengaruh dari kebenaran firman Tuhan kepada orang Indonesia yang memiliki kebudayaan terbuka dan mudah menyesuaikan tersebut, namun memang di sisi lain juga ada tantangan dalam mempertahankan orang Kristen Indonesia untuk terus konsisten mempertahankan prinsip alkitabiahnya. Namun penanaman nilai-nilai Kristen Alkitabiah yang kuat dalam diri orang-orang Kristen Indonesia dapat menjadi sintesa dari dialektika tersebut. Gereja harus menangkap peluang dari keterbukaan kebudayaan dan kemampuan orang Indonesia yang cepat beradaptasi dengan kehadiran prinsip baru. Namun setelah mendapatkan mereka, gereja harus mampu mempertahankan orang Kristen Indonesia dalam nilai-nilai iman Kristen dan terus menerus mempertahankan mereka untuk tetap tinggal dalam nilai-nilai iman Kristen alkitabiah, tidak peduli seberapa besar gelombang perubahan yang berusaha mengikis kembali nilai-nilai Kristen mereka. Gereja harus mengingat selalu dan tetap waspada akan datangnya gelombang perubahan selanjutnya, karena kebudayaan pragmatis melekat dan bahkan mungkin mendarah daging pada kehidupan orang-orang Indonesia, termasuk orang-orang Kristen Indonesia.

\section{DAFTAR RUJUKAN}

Andersen, P. A., M. L. Hecht, G. D. Hoobler, and M. Smallwood. (2003). "Nonverbal Communication Across Cultures," in Cross-Cultural and Intercultural Communication, W. B. Gudykunst, ed. Thousand Oaks, CA: Sage Publications.

\section{KESIMPULAN}

Penganut pandangan antitesa dan dualis (Christ against Culture dan Christ and Culture in Paradox)—atau mungkin juga kaum transformationalists (Christ, Transformer Culture)-mungkin menolak usaha mensintesakan iman Kristen dan kebudayaan dan curiga bahwa sintesa tersebut dipandang sebagai versi terselubung penyesuaian budaya dengan Injil seperti yang dilakukan kaum equates (Christ of Culture). Fakta riil dalam pelayanan Injil atau gereja-gereja di Indonesia terbukti bahwa menghindari interaksi dengan kebudayaan dalam pemberitaan Firman atau pemberitaan Injil adalah hal yang tidak mungkin, walaupun beberapa orang mungkin merasa dapat melakukannya.

Mengaitkan prinsip dan nilai iman Kristen, khususnya keyakinan Injili dan konservatif dengan hasil riset Hofstede tentang kebudayaan Indonesia menunjukkan banyak kontradiksi atau dialektika antara iman Kristen dan kebudayaan Indonesia. Dialektika antara individualisme-kolektivisme, dialektika kepastian dan penghindaran ketidakpastian, dialektika kesetaraan dan jarak kekuasaan, dialektika nilai maskulinitasfemininitas, dan dialektika orientasi jangka panjang dan jangka pendek. Setiap dialektika tersebut memberikan tantangan dalam pelayanan dan pemberitaan Injil di Indonesia. Beberapa sintesa yang disajikan dalam artikel ini diusulkan dapat menjadi solusi alternatif bagi beberapa contoh dialektika iman Kristen dan kebudayaan Indonesia.

Gudykunst, W. B. (2001). Asian American Ethnicity and Communication. Thousand Oaks, CA: Sage Publications.

Hofstede, G., G. J. Hofstede, and M. Minkov (2010). Cultures and Organizations: Software of the Mind, 3rd ed. New York: McGraw-Hill. 
Hofstede, G. (1984). Culture's consequences. Beverly Hills, CA: Sage

Lavine, T. Z. (2003). Hegel: Revolusi dalam Pemikiran. Yogyakarta: Penerbit Jendela.

Lonner, W.J. and R.S. Malpass. (1994). "When Psychology and Culture Meet: Introduction to Cross-Cultural Psychology," in Psychology and Culture, W. J. Lonner and R. S. Malpass, eds. Boston: Allyn and Bacon.

Lukito, D. L. (2011). "The Undending Dialogue of Gospel and Culture" dalam Struging in Hope: A Tribute the Rev. Dr. Eka Darmaputra, editor Ferdinand Suleeman, Adji Ageng Sutama \& A. Rajendra. Jakarta: BPK Gunung Mulia. Malina, B. J. \& R. L. Rohrbaugh, (2003). Social-Science Commentary on the Synoptic Gospels. Minneapolis: Fortress Press.

Niebuhr, H. R. (1995). Kristus dan Kebudayaan. Jakarta: Petra Jaya.

Purwanto, E. (2016). Manajemen Lintas Kebudayaan. Tangerang: Yayasan Pendidikan Philadelphia.

Purwanto, E. (2018). Moderation Effects of Power Distance on the Relationship Between Job Characteristics, Leadership Empowerment, Employee Participation and Job Satisfaction: A Conceptual Framework, Academy of Strategic Management Journal, Volume 17, Issue 1, pp. 1-9.
Russell, B. (2013). Bertuhan Tanpa Agama: Esai-esai Bertrand Russell tentang Agama, Filsafat dan Sains. Yogyakarta: Resist Book.

Samovar, L. A., R. E. Porter, E. R. McDaniel \& C. S. Roy (2013). Communication Between Cultures, Eighth Edition (Boston, MA: Wadsworth, Cengage Learning.

Suleeman, F. dan I. Rakhmat (1990). Masihkah Benih Tersimpang? Kumpulan Karangan dalam Rangka Peringatan 50 Tahun Gereja Kristen Indonesia Jawa Barat. Jakarta: BPK Gunung Mulia.

Triandis, H. C. (1990). "Cross-Cultural Studies of Individualism and Collectivism," in Cross-Cultural Perspectives, J. J. Berman, ed. Lincoln, NE: University of Nebraska Press.

Ukur, F. (2011). "Teologi Kejelataan" dalam Struging in Hope: A Tribute the Rev. Dr. Eka Darmaputra, editor Ferdinand Suleeman, Adji Ageng Sutama \& A. Rajendra. Jakarta: BPK Gunung Mulia

Wibisono, C. (1990). "Absolutisme Vertikal dan Toleransi Horisontal" dalam Masihkah Benih Tersimpang? Kumpulan Karangan dalam Rangka Peringatan 50 Tahun Gereja Kristen Indonesia Jawa Barat, disunting oleh $\mathrm{F}$. Suleeman dan loanes Rakhmat. Jakarta: BPK Gunung Mulia 